\title{
Effectiveness of Mint Leaf Extract (Mentha Piperita Linn.) on Menstrual Pain Level in Adolescents
}

\author{
$1^{\text {st }}$ Wijayanti \\ Aisyiyah University of Yogyakarta \\ Yogyakarta, Indonesia \\ School of Health Science Kusuma Husada \\ Surakarta \\ haryantowijayanti@gmail.com
}

\author{
$2^{\text {nd }}$ Ernawati \\ Aisyiyah University of Yogyakarta \\ Yogyakarta, Indonesia \\ School of Health Science Kusuma Husada \\ Surakarta \\ ernamamafadil@gmail.com
}

\author{
$3^{\text {rd }}$ Arista Apriani \\ Aisyiyah University of Yogyakarta \\ Yogyakarta, Indonesia \\ School of Health Science Kusuma Husada \\ Surakarta \\ arista_apriani@yahoo.com
}

\begin{abstract}
Background: Menstrual pain is cramping and excessive pain experienced by women during menstruation. The impact of menstrual pain can result in a woman being forced to leave work and disrupt daily activities. Non pharmacological therapy is also needed to reduce menstrual pain, mint scent found in mint leaves is useful for reducing nausea, headaches and pain during menstruation. The purpose of this study was to analyze the differences in the effectiveness of giving mint (Mentha Piperita Linn.) leaf extract to the level of menstrual pain in adolescents. Methods: This was a quasi-experimental study with a nonrandomized control group pretest posttest design. Bourbaris pain numerical scale to measure the menstrual pain scale before and after the intervention was carried out in 15 respondents in the intervention group and 15 respondents in the control group (without treatment). Data analysis employed the Shapiro Wilk normality test, the effectiveness of the intervention group before and after treatment with the Wilcoxon test, the difference between the two groups with the Mann-Whitney Test. Results: There was a difference in the level of menstrual pain before and after the intervention by giving mint extract with $\mathrm{z}$ value $=-3,557$ and a significance value of $0,000(\mathrm{p}<0.05)$. Administration of mint leaf extract was more effective in reducing menstrual pain compared to the control group with $\mathrm{z}$ value $=-4,472$ and significance value $0,000(\mathrm{p}<0.05)$.
\end{abstract}

Keywords: mint leaf extract, menstrual pain, teenagers

\section{INTRODUCTION}

Menstrual pain is cramping and excessive pain experienced by a woman during menstruation. Menstrual pain is often referred to as dysmenorrhea [1]. The incidence of menstrual pain according to WHO (World Health Organization) is more than 50\%. In Indonesia the incidence of menstrual pain is 55\% [2]. Menstrual disorders become a major problem in women in Indonesia [3]. Problems perceived by adolescents related to menstruation are dysmenorrhea $67.2 \%$ and pre-menstruation syndrome $63.1 \%$ [4].

Menstrual pain results from endometrium containing high amounts of prostaglandin during the luteal phase in the menstrual cycle, causing strong myometrium contractions and being able to constrict blood vessels that cause ischemia, endometrial disintegration, bleeding and pain. In general menstrual pain occurs discomfort in 1-2 days before menstruation and most severe pain during the first 24 hours of menstruation [5].

Menstrual pain experienced by each woman is different, some are slightly disturbed, so disturbed that they cannot carry out daily activities until they have to take a break even to be absent from work / school [6] The impact of menstrual pain (dysmenorrhea) can result in a woman being forced to leave her work and disrupt daily activities and sometimes even can make someone helpless or faint [7].

Factors causing menstrual pain in adolescent women are nutrition, medication, physical activity, the environment and stress (physical, emotional and mental). The predisposing factor for menstrual pain is from psychosocial factors [8].

The way to overcome dysmenorrhea or menstrual pain can be done in two ways, namely by nursing (compressing with hot water bottles, regular exercise, rest and relaxation, yoga) and medical care (analgesics, estrogen and progesterone administration, and supplementation) and non-pharmacological measures (giving mint leaf tea) [9].

One of the herbs that can be used to reduce menstrual pain is mint leaves. Mint leaves are a very thirsty plant, growing well in the dried Mucklands in Indiana, Michigan, Wisconsin, Oregon, Washington, Idaho, South Dakota and Montana. Mint leaves can grow in the lowlands and highlands, so it is easy to be cultivated in subtropical areas. The content of mint leaves is menthol (73.7-85.8\%), menthone and methyl acetate [10]. In addition, monoterpene, menthofuran, sesquiterpene, triterpene, flavonoid, carotenoid, tannin and several other minerals are also found from mint leaves [11].

The content of menthol on mint leaves can be used as a carminative (sedative), antispasmodic and diaphoretic (warms up and induces sweat) drug. Mint leaves are good for the body, such as cooling the digestive tract, or if an upset stomach helps relieve the pain. Mint leaves are very thirsty plants. It grows in the well-drained Mucklands in Indiana, Michigan and Wisconsin. It also grows well in Oregon, Washington, Idaho, South Dakota and Montana. The aroma of mint 
the number of samples used 30 research subjects with the division of samples for the experimental group of 15 subjects, while the control group samples were 15 subjects.

Previously conducted a data normality test with the Shapiro Wilk test. Analysis of the data used is for the mean difference before and after treatment in the experimental group using the Wilcoxon test and for differences in the difference using the Mann Whitney test

\section{FINDING AND DISCUSSION}

a. Mint leaf extract to pain levels menstruate in young women.

Table 3.1 Results of measurement of menstrual pain levels before and after giving mint leaf extract $(\mathrm{N}=15)$

This type of research will be used is a quasiexperimental study with a non-randomized control group pretest posttest design. This study cannot control the confounding variables which include food intake, activity, psychology and hormonal imbalances. Pretest and post-test were in the form of a direct assessment of the menstrual pain scale using a scale of $1-10$, pre-test was carried out before the intervention is given, while the post test was carried out after the intervention. The experimental group with the intervention in the form of giving mint leaf extract, while the control group is placebo (plain water / without mint leaf extract). Mint leaf extract is 5-10 pieces of fresh mint leaves brewed with $450 \mathrm{ml}$ of hot water, brewed and allowed to stand 5-10 minutes then add sugar according to taste. The intervention began to be given the subject when experiencing menstrual pain both the experimental group and the control group, with the measurement of the pain scale (pre-test), 30 minutes after the intervention was then measured the pain scale (post-test). Interventions were carried out as much as 1x a day for 1 day, intervention in the experimental group was given mint leaf extract and the control group was given a placebo. Pain scale measurement is done before and after the intervention, so that it can be seen changes (up / down) menstrual pain experienced by the subject both the experimental group and the control group.

This research was conducted at the STIKes Kusuma Husada Surakarta campus located on J1. Jaya Wijaya No.11 Kadipiro Mojosongo Surakarta in January to August 2018. The sampling technique in this study was carried out using a non-probability sampling technique with consecutive sampling, which was to take all samples that met the inclusion and exclusion criteria throughout the study. Criteria for inclusion of young women who experience dysmenorrhea, young women are not allergic to mint leaves, young women are willing to be respondents. Criteria for Exclusion of young women in the treatment of menstrual cycles, young women with menstrual abnormalities/have menstrual disorders. In this study

\begin{tabular}{lccc}
\hline Group I & Mean & $\begin{array}{l}\text { Minimal } \\
\text { pain level }\end{array}$ & $\begin{array}{c}\text { Maximum } \\
\text { pain level }\end{array}$ \\
\hline $\begin{array}{l}\text { Before the } \\
\text { intervention }\end{array}$ & 3.00 & 2 & 4 \\
$\begin{array}{l}\text { After the } \\
\text { intervention } \\
\text { (30 minutes) }\end{array}$ & 1.93 & 1 & 3 \\
\hline
\end{tabular}

Examination of menstrual pain levels is carried out at the beginning and end of the study. The results showed that the mean initial menstrual pain level was 3.00 , the average end pain level was 1.93 . The mean initial pain level was 3.00 with a minimum value of 2 and a maximum of 4. The average final pain level of 1.93 with a minimum value of 1 and a maximum of 3 .

b. Without the provision of intervention / control of the level of menstrual pain.

Table 3.2 Results of measurement of menstrual pain levels before and after without giving intervention / control $(\mathrm{N}=15)$

\begin{tabular}{lccc}
\hline Group II & Mean & $\begin{array}{l}\text { Minimal } \\
\text { pain level }\end{array}$ & $\begin{array}{l}\text { Maximum } \\
\text { pain level }\end{array}$ \\
\hline $\begin{array}{l}\text { Before the } \\
\text { intervention }\end{array}$ & 3.13 & 2 & 4 \\
$\begin{array}{l}\text { After the } \\
\text { intervention } \\
(30 \text { minutes) }\end{array}$ & 3.40 & 2 & 5 \\
\hline
\end{tabular}

Examination of menstrual pain levels is carried out at the beginning and end of the study. The results showed that the average level of initial menstrual pain was 3.13 , the average level of late menstrual pain was 3.40. The average level of menstrual pain 3.13 with a minimum value of 2 and a maximum of 4 . Average level of final menstrual pain 3.40 with a minimum value of 2 and a maximum of 5 .

c. Mint leaf extract on the level of menstrual pain in young girls. 
Table 3.3 Test for normality of menstrual pain levels before and after administration of mint leaf extract $(\mathrm{N}=15)$

\begin{tabular}{llll}
\hline \multicolumn{1}{c}{ Group I } & Mean & SD & Sig. \\
\hline $\begin{array}{l}\text { Before the } \\
\text { intervention }\end{array}$ & 3.00 & 0.926 & 0.001 \\
$\begin{array}{l}\text { After the } \\
\text { intervention } \\
\text { (30 minutes) }\end{array}$ & 1.93 & 1.033 & 0.000 \\
\hline
\end{tabular}

Based on table 3.3 above it can be seen that the results of the normality test using Shapiro Wilk results before the intervention is carried out for 30 minutes, the significance value is smaller than the alpha value $(0.001$ $<0.05)$ and after the intervention the significance value $(0.000<0.05)$ then $\mathrm{H} 0$ was rejected. Data on the level of menstrual pain before and after intervention (30 minutes) in group I were not normally distributed, so using a non-parametric test with the Wilcoxon test which results in the difference in the significance value with the value of $Z=-3,557$ value of $\mathrm{P}=0,000 \quad(<0.05)$ so it can be concluded that there were significant differences before and after giving mint leaf extract.

d. Without the provision of intervention / control of menstrual pain levels in adolescent girls

Table 3.4 Test for normality of menstrual pain levels before and after no intervention $(\mathrm{N}=15)$

\begin{tabular}{llcl}
\hline Group II & Mean & SD & Sig. \\
\hline $\begin{array}{l}\text { Before the } \\
\text { intervention }\end{array}$ & 3.13 & 0.51 & 0.000 \\
$\begin{array}{l}\text { After the } \\
\text { intervention } \\
\text { (30 minutes) }\end{array}$ & 3.40 & 0.82 & 0.052 \\
\hline
\end{tabular}

Based on table 3.4 above, it can be seen that the results of the normality test using Shapiro Wilk results before the intervention is done, the significance value is smaller than the alpha value $(0,000<0.05)$ and after the intervention the significance value (0.052> 0.05 ) then $\mathrm{H} 0$ was rejected. Data on the level of menstrual pain before and after the intervention (30 minutes) in group II were not normally distributed, so using a non-parametric test with the Wilcoxon test the results of the difference in significance with the value of $Z=-1,633$ value of $\mathrm{P}=0.102(>0.05)$ so it can be concluded There were no significant differences before and after the administration of intervention/control.

e. Difference between differences in menstrual pain levels in the intervention group of mint leaf extract with no intervention / control.
Table 3.5 Test results for the difference in normality of menstrual pain levels in the intervention group of mint and control extracts $(\mathrm{N}=30)$

\begin{tabular}{lccc}
\hline $\begin{array}{l}\text { Groups I and } \\
\text { II }\end{array}$ & Mean & SD & Sig. \\
\hline $\begin{array}{l}\text { Difference in } \\
\text { pain level }\end{array}$ & 0.40 & 0.855 & 0.001 \\
\hline
\end{tabular}

Based on table 3.5 describes the significance value of groups I and II is smaller than the alpha value $(0.001<0.05)$, then $\mathrm{Ho}$ is rejected. The results of the test for the difference in normality of menstrual pain levels in the intervention group of mint leaf extract and without the intervention/control were not normally distributed.

Differences in the average level of menstrual pain before and after intervention in groups I and II using the non-parametric MannWhitney Test because data are not normally distributed and the two groups are not interconnected, can be seen in table 3.6 below:

\section{Test Statistics ${ }^{\mathrm{a}}$}

\begin{tabular}{|l|l|}
\hline & selisih \\
& K1 KII \\
\hline Mann-Whitney U & 11,500 \\
Wilcoxon W & 131,500 \\
Z & $-4,472$ \\
Asymp. Sig. (2-tailed) &, 000 \\
Exact Sig. [2*(1-tailed Sig.)] &, $000^{\mathrm{b}}$ \\
\hline
\end{tabular}

a. Grouping Variable: Kelompok 1 dan 2

b. Not corrected for ties.

Based on table 3.6 above, it can be seen that the difference between the experimental group and the significance control is smaller than the alpha value $(0,000<0.05)$, so $\mathrm{Ho}$ is rejected, there is a difference in the level of menstrual pain between the experimental group and the control group.

Based on the results of the study, it was found that by giving mint leaf extract to teenage girls can effectively reduce menstrual pain in teenage girls. Giving mint leaf extract as much as $450 \mathrm{cc}$ to young women with menstrual pain because in the mint leaf there is a Menthol content that has efficacy as a carminative (sedative), antispasmodic and diaphoretic (warm and induce sweat) drug. So that menstrual pain experienced by adolescents will be suppressed or can be controlled by the presence of menthol contained in mint leaf extract. Extraction of mint leaves is a non-pharmacological drug that is very practical in its manufacture, effective and efficient in reducing menstrual pain and 
easy in its manufacture. Society, especially young women, is easier to make extracts of the mint leaves, so the use of pharmacological drugs used to suppress pain (anti-pain) can be suppressed.

Based on the tabulation table the results of measurements of menstrual pain levels before and after administration of mint leaf extract intervention in the experimental group, showed that the level of menstrual pain decreased. There was a difference in the level of menstrual pain before and after the mint leaf intervention was given. Menstrual pain experienced by young women is a process of strong myometrial contractions in the lining of the uterus so that the blood vessels become narrowed (ischemia, endometrial disintegration, bleeding and pain). Menstrual pain causes symptoms of stomach discomfort [14].

When observing the research subjects prior to the intervention they were known to appear to feel pain in the abdomen and dizziness, thus causing fear and feeling discomfort when attending lectures. If this condition is not treated immediately, the impact will be caused by interfering with the activity until the loss of concentration (unconscious / unconscious) due to withstand the pain experienced. Given the complications that will occur, sufferers should take medication to reduce complaints experienced. With nonpharmacological treatment it is hoped that it can have a decreased effect on menstrual pain and minimize the use of pharmacological drugs because continuous use can cause adverse effects to the body. Non-pharmacological treatment is given in the form of mint leaf extract, the content of mint leaves is menthol (73.7-85.8\%), menthone and methyl acetate [10]. In addition, monoterpene, menthofuran, sesquiterpene, triterpene, falvonoid, carotenoid, tannin and several other minerals are also found from mint leaves [11]. Menthol found in mint leaves can reduce headaches and pain during menstruation [15].

After being given mint leaf extracts in the experimental group, menstrual pain was seen with complaints of abdominal pain which could be reduced because menthol contained in mint leaves had antispasmodic properties, thus reducing contractions in the myometrium. Dizziness complaints in the experimental group also decreased due to mint leaves as a carminative (sedative) drug. Where as in the control group given a placebo that is white water without mint leaves. So that in the experimental group decreased levels of menstrual pain while in the control group did not experience a decrease in menstrual pain levels.

Mint leaf extract is a healing that comes from nature by using mint leaves as raw material. Mint leaves contain menthol so it is often used as a raw material for medicine [16]. Menthol found in mint leaves has antispasmodic, carminative and diaphuretic drugs. Besides mint leaves also help treat infections. Mint leaves can reduce the level of menstrual pain so there are no complaints due to menstrual pain. Extract is a process of withdrawal of soluble chemicals that are separated from insoluble materials by liquid solvents [17]. The use of mint leaf extract is indicated to reduce the level of menstrual pain.

In this study the technique of intervening in the form of mint leaf extract is done for $1 \mathrm{x}$ a day when menstrual pain is experienced. But do not rule out the existence of other influences that can reduce the level of menstrual pain, for example nutrition, rest, relaxation, yoga, activity, psychological state and hormonal influences. Thus mint leaf extract can reduce the level of menstrual pain in young women. Efforts to reduce the clinical symptoms of menstrual pain levels in adolescent girls in addition to using pharmacological drugs can also use nonpharmacological. Mint leaves contain menthol essential oil which can reduce the level of menstrual pain in young women.

\section{IV.CONCLUSION}

There is effectiveness in giving mint leaf extract (Mentha Piperita Linn) to the level of menstrual pain in young women. Management of menstrual pain based on Evidence Based Practice also needs to consider ways and methods in its implementation, not all treatments can be applied to menstrual pain cases because it depends on the patient's condition and food intake.

The limitation in this study is that it cannot conduct sample selection on the influential processes (not all influencing factors can be controlled). Factors that cannot be controlled include food intake, activity, psychology and hormonal imbalances.

It is hoped that young women can use nonpharmacological therapies such as mint leaf extract in reducing menstrual pain to reduce and treat menstrual pain so that it does not interfere with activity.

\section{ACKNOWLEDGMENT}

This research received funding from the internal lecturer research at the Surakarta Institute of 
Mentha piperita L. Grown in Sultanate of Oman.

Health Sciences Kusuma Husada. The author would like to thank profusely to all those who helped and were involved in this research, especially the Kusuma Husada College of Health Sciences Surakarta and the respondents.

\section{REFERENCES}

[1] L. Wang et al., "study," pp. 1021-1027, 2004

[2] ACOG. 2015. Menstruation in Girls and Adolescents: Using The Menstrual Cycle as a Vital Sign. The American College of Obstetricians and Gynecologists.Available: http://www.acog.org/-/media/CommitteeOpinions/CommitteeonAdolescentHealthCare/ c0651.pdf?dmc=1\&ts=20124T1701404887, diakses tanggal 3 Juni 2018.

[3] Damayanti S. 2013. Faktor-faktor yang berhubungan dengan premenstrual syndrome pada mahasiswa D-4 Kebidanan di Sekolah Tinggi Ilmu Kesehatan U'budiyah Banda Aceh.

[4] Sharma P, Malhotra C, Taneja DK., Saha R. 2008. Problems Related to Menstruation Amongst Adolescent. Indian J. Pedriatic, 75 (2): 125-9

[5] Geri, Morgan dan Carol Hamilton. 2009. Obstetri dan Ginekoligi Panduan Praktik. Jakarta: EGC

[6] Andriyani A. 2013. Panduan Kesehatan Wanita. Surakara: As-Salam Publisher pp.12,33.

[7] Proverawati A, Misaroh M. 2009. Menarche. Menstruasi Pertama Penuh Makna. Yogyakarta ; Nuha medika.

[8] Anurogo D, Wulandari A. 2011. Cara Jitu Mengatasi Nyeri Haid. Yogyakarta : Andi Offset.

[9] Andhyantoro I, Kumalasari I. 2012. Kesehatan Reproduksi. Jakarta : Salemba Medika.

[10] Hadipoentyanti. 2012. Pedoman Teknis Mengenal Tanaman Mentha (Mentha arvensis L.) dan Budidayanya. Sirkuler Teknologi Tanaman Rempah dan Obat. Balai Penelitian Tanaman Rempah dan Obat, Bogor.

[11] Hossain MA, SS Al-Hdhrami AM, Weli Q, AlRiyami, and JN Al-Sabahi.. 2014. Isolation, Fractionation and Identification of Chemical Constituents from The Leaves Crude Extracts of
Asian Pac. J. Trop. Biomed. 4 (1): 368-372.

[12] Siswantoro E and Whitney U. (no date) 'Jurnal Keperawatan dan Kebidanan -Stikes Dian Husada Mojokerto', pp. 49-56.

[13] J Tillett and D Ames. 2010. "The Uses of Aromatherapy in Women's Health." vol. 24, no. 3 , pp. 238-245,

[14] Patil SH et al. 2012. Evaluation of anthelmintic activity of Uncaria gambier Roxb. against Pheretima posthuma. Int. J. Drug Dev \& Res, 4(4), pp. 234-238.

[15] Tiran, D. 2008. Clinical Aromatherapy for Pregnancy and Childbirth. Philadelphia : Elsevier Churchill Livingstone.

[16] Hidayat F, Rurini R, Soebiantoro. 2013. Isolasi dan Karakterisasi Komponen Minyak Mint dari Daun Mentha Arvensis Linn Hasil Distilasi Air. Jurnal Murid Kimia.2(2): 567-573

[17] Badan Pengawasan Obat dan Makanan [BPOM]. 2012. Cara pembuatan obat tradisional yang baik. Indonesia, BPPOM RI. 